ARTICLE

\title{
Business sentiments during India's national lockdown: Lessons for second and potential third wave
}

\author{
Bornali Bhandari $^{1} \cdot$ Samarth Gupta ${ }^{2}$ - Ajaya K. Sahu + K. S. Urs ${ }^{1}$
}

Accepted: 12 October 2021 / Published online: 29 November 2021

(c) The Author(s) under exclusive licence to Editorial Office, Indian Economic Review 2021

\begin{abstract}
The implementation of the COVID-19 national lockdown announced suddenly in March 2020 in India provided a unique opportunity to capture real-time changes in business sentiments during episodes of unexpected and sudden disruptions. Using a logit-probability model to analyse data of this natural experiment showed that firms' 6-months ahead sentiments for its financial condition worsened drastically during lockdown compared to firms surveyed immediately prior to the announcement. Further, smaller firms showed a relatively higher impact. We also find that firms perceive this as a relatively higher demand shock in terms of falling domestic sales post-lockdown whereas supply shocks are perceived to be on the downside. Lastly the mitigation strategy of firms involved reducing employment for unskilled workers and wages for skilled workers. This unique study gives insights not only about firms and their strategies but regarding appropriate policy choices during lockdown. The lessons are applicable for governments which imposed local lockdowns during the second wave and potential disruption for the expected third wave.
\end{abstract}

Keywords Business sentiments · Expectations · COVID-19 $\cdot$ Lockdown $\cdot$ Sales · Employment $\cdot$ Wages $\cdot$ Meta-data $\cdot$ MSMEs

\footnotetext{
The data set used in this paper is sourced from NCAER Business Expectations Survey, which the institution sponsors. The authors are grateful to NCAER for letting them use the data. We are thankful to an anonymous referee for providing useful comments.

Samarth Gupta

samarth@bu.edu

Bornali Bhandari

bbhandari@ncaer.org

Ajaya K. Sahu

aksahu@ncaer.org

K. S. Urs

ksurs@ncaer.org

1 NCAER, New Delhi, India

2 Amrut Mody School of Management, Ahmedabad University, Ahmedabad, India
} 
JEL Classification $\mathrm{E} 32 \cdot \mathrm{J} 21 \cdot \mathrm{J} 31$

\section{Introduction}

The incidence of the once-in-a-century global pandemic, novel coronavirus (COVID-19) has upended the world as we know it. Adoption of several non-pharmaceutical interventions known as social distancing measures were supposed to help reduce the transmission of the influenza virus as per historical experiences from previous pandemics (Hatchettet al., 2007). However, the same measures had a dampening effect on economic activity (Bell \& Lewis, 2005; Eichenbaum et al., 2020). Faced with the difficult choice between lives and livelihoods, the Government of India imposed a 'sudden' lockdown on 24th March 2020, effective from 25th March 2020 for 21 days (PIB, 2020a). The lockdown was extended from April 14, 2020 to May 3, 2020 (PIB, 2020b).

India had one of the toughest lockdowns around the world with a stringency index of 100 (Hale et al., 2020). Government of India offices \& its autonomous/ subordinate offices \& public corporations; State/Union Territory Governments \& their autonomous bodies \& corporations; commercial and private establishments (with exceptions); industrial establishments (with exceptions); transport services; hospitality services; educational, training, research, coaching institutions, etc. and places of worship were to remain closed with public gatherings barred (PIB 2020a). In addition to its stringency and suddenness, the horizon of the lockdown also remained uncertain. While initially, it was planned for a duration of 21 days, Phase 3 of the partial lockdown has been extended till May 17, 2020. The unlocking of the economy ultimately began in a phase-wise manner in June 2020.

The National Council of Applied Economic Research (NCAER) Business Expectations Survey (N-BES from hereon) was being conducted (on-field) in the month of March 2020. The survey continued in the digital mode as the lockdown was announced and through it as well. The objective of this paper is to utilise the lockdown as an exogenous, sudden and uncertain business disruption shock and understand how businesses change under such events. Further, our data (explained later) also allows us to assess the demand and/or supply channel through which the firms felt the shock and its resultant impact on hiring and wages for skilled and unskilled labour. Such an investigation is important to understand the initial response by firms to the pandemic. With the threats of mutations on the rise and slow vaccination rollout in large parts of the developing world, non-pharmaceutical interventions such as snap lockdowns are likely to be utilised. Thus, our exercise not only helps to detect fluctuations in economic activity but the choices firms may make to mitigate the impact. This has important policy implications for the government who can use the data to devise policies for firms and develop appropriate social welfare benefits for labour.

Using a logit probability model, the survey finds that firms' sentiments regarding its own conditions worsened for both small and large firms post-lockdown but the smaller firms perceived a larger worsening. Firms perceived a relatively larger negative demand shock as opposed to a supply shock. Post-COVID 19 lockdown, a 
firm was 11.2 percent more likely to expect a decline in 6-months ahead domestic sales while likelihood of raw material costs going up declined by 19.1 percent. As a mitigation strategy, firms were more likely to decrease the employment of unskilled workers and reduce the wages of skilled workers in the next 6 months.

The key contribution of this paper is that it captured the real-time changes in business sentiments in India during the national lockdown. While some recent papers have observed changes in stock market indices and text-based measures of sentiments (Baker et al., 2020a; Hassan et al., 2020), this is the first academic paper of its kind in India which captures the changes in business sentiments, its channels and possible mitigation policies of firms in a systematic and scientific manner.

Our results helped us gain several key insights on the nature of the impact as perceived by businesses. Specifically, we find that firms perceived the lockdown as a demand-side shock. This insight indicates that only supply-side interventions, such as easy credit availability, without complementary consumer spending, would not have been sufficient in resuming business sentiments. This is in stark contrast with the credit guarantee schemes that the Government of India introduced to help combat businesses with the downturn.

While there was no national lockdown during the second wave of the pandemic, several states imposed local lockdowns. Understanding the expectations and mitigation strategies of businesses can help state governments enable businesses to rebound faster.

The paper is divided into five sections. The next section explains the N-BES methodology. The third section describes the data and the fourth section presents the key empirical results. The fifth section presents the key conclusions of the paper.

\section{NCAER Business Expectations Survey}

\subsection{Survey coverage}

The N-BES has been evaluating business sentiments every quarter since 1991. Business sentiments are typically based on opinion surveys on production, inventory, orders, etc. They are used to monitor output growth and anticipate turning points to essentially forecast future economic fluctuations (Kauffman, 1999; Klein \& Moore, 1991; Lindsey \& Pavur, 2005; Banerjee \& Marcellino, 2006; Lahiri \& Monokroussos, 2013; OECD, 2020). The advantage of sentiments data are two-fold i.e. they are timely and can capture real-time changes. Second, they are not subject to revisions like macroeconomic data (Koenig, 2002; Christiansen et al., 2014; Baker et al., 2020b).

The N-BES sample is spread over six cities namely Delhi National Capital Region representing the North, Mumbai and Pune representing the West, Kolkata representing the East, and Bangalore \& Chennai from the South. Interpreting the findings with regard to the business sentiments of the firms surveyed in these six cities as a barometer of national business sentiments is based on the assumptions that 
firms' sentiments in other cities/towns in the four regions are influenced by business sentiments of the cities that are represented in the survey.

Industries are adequately represented with regard to ownership type (namely, public sector, private limited, public limited, partnership/individual ownership, and MNCs), industry sector (namely, consumer durables, consumer non-durables, intermediate goods, capital goods, and service sector), and firm size based on their annual turnovers (in the range of less than ₹ 1 crore, ₹ 1-10 crores, ₹ 10-100 crores, $₹ 100-500$ crores and more than ₹500 crores).

\subsection{Survey procedure}

The sample is based on Directories of Industries and open selection from industrial clusters/areas in the selected cities. The study is conducted every quarter, of which 25-30 days are strictly allotted for the fieldwork. It is ensured that balanced representation of firms in terms of size and sector is maintained in the sample. In March 2020, we completed the 112th Round.

Typically the survey has been conducted using in-person interviews with middle-level officials or entrepreneurs in small firms as respondents. As another way of conducting the survey, during the last four rounds, online survey had been initiated through sending the Google Form link to respondents. More than 10 percent of total respondents have participated through the online survey in each round.

The N-BES survey ran from 2nd March to 3rd April and there were 426 responses. In view of the lockdown due to COVID-19, in person interviews were not possible for a sizeable number of days during the 112th Round (March 2020) and for this quite a number of respondents were interviewed telephonically and questionnaires were canvassed through that. Due to the lockdown, all survey activities at NCAER had to move from paper-based to online or telephonic telephone-based surveys. A combination of methods like online/telephone and traditional pen and paper surveys were used to canvass the BES. About 15 percent of the responses obtained in this Survey were online.

\subsection{Survey content}

Business sentiments are captured by four components namely assessment of overall economic conditions over the next 6 months, financial position of the firms over next 6 months, present investment climate as compared to 6 months ago and present capacity utilisation compared to its optimal level. Within these, financial position of the firm captures microeconomic expectations about firm's condition 6 months from now. Firms can respond by saying better, same or worse. The NCAER Business Confidence Index (N-BCI) is computed using the above four indicators where all four of them have equal weights.

Apart from that, firms are asked about firm-specific expectations on parameters like changes in input and output cost, labour employment and wages, inventories, prospects for sales, production, exports/imports, prices of their produce, profit situation, inventories, order books, etc. They are asked about changes in the last 3 months 
and their expected changes in next 6 months as compared to now. Firms are also asked about labour employed by four types - managerial/skilled, unskilled, casual/ temporary and permanent. Skilled workers in the N-BES are defined as those that do complicated tasks that require specific skill sets, training and experience. Questions about hiring different types of workers over the previous 3 months and prospects of hiring over the next 6 months are asked. Wage rates for managerial/skilled and unskilled workers are also probed.

\subsection{Ensuring survey quality}

Information on respondent details, company details, and date of interview are collected. As a principle, official business cards of respondents are required with each filled-in questionnaire. In case of absence of one, companies stamp and complete address, designation and contact number of respondents are to be provided. These are used to conduct random follow-up with the respondents and also fill the gaps if required. Generally follow up is done with $20 \%$ of respondents to ensure the quality of the survey. In addition, inter-linkage among various sections of the questionnaire helps check the reliability and consistency of responses.

\subsection{Correlation of business confidence index with macroeconomic aggregates}

Using quarterly data from 2011-12:Q1 to 2020-21:Q1, we test N-BCI's statistical relationship with the Index of Industrial Product and Gross Valued Added (GVA) manufacturing. We use the growth rates of seasonally averaged, cyclical components of the two aggregates. Hodrick-Prescott filter is used to separate the trend and cyclical components (Hodrick \& Prescott, 1997). The N-BCI is considered to be a cyclical indicator and therefore neither is it seasonally averaged nor is the HodrickPrescott filter used. All of them were stationary at the $10 \%$ level of significance and so was the growth rate of the N-BCI. The cross-correlogram reported in Appendices, 1 and 2 show that the N-BCI is a leading indicator for both of them. However, the Engle-Granger causality test confirms that the N-BCI is a leading indicator of IIP (Appendix 3). This suggests that the N-BCI tracks the turning points in industrial activity and can be considered useful as a metric of industrial activity.

\section{Summary statistics}

The N-BES investigates sentiments and expectations of firms regarding key economic variables and decisions. Table 1 provides summary statistics for some of these expectations in March 2020.

- Panel-A provides expectations on demand and supply factors as perceived by firms. On average, firms expected a 0.9 percentage points decline in domestic sales over the next 6 months compared to March 2020. The standard deviation was 7.9 indicating a considerable variation across 288 firms which provided this 
Table 1 6-months ahead expected percentage change

\begin{tabular}{lrll}
\hline & Mean & $\begin{array}{l}\text { Standard } \\
\text { deviation }\end{array}$ & Observations \\
\hline Panel-A: demand and Supply Factors & & \\
Firm's domestic sales & -0.90 & 7.90 & 288 \\
Raw material costs & 2.78 & 4.33 & 255 \\
Panel-B: employment change & & & \\
Skilled workers in firms & 1.05 & 3.48 & 315 \\
Unskilled workers in firms & 0.38 & 4.05 & 268 \\
Panel-C: wage change & & & \\
Skilled workers in firms & 3.97 & 4.64 & 352 \\
Unskilled workers in firms & 3.18 & 4.01 & 326 \\
\hline
\end{tabular}

Source: Authors' computations from the NCAER BES survey round 112

response. Similarly, the average 6-months ahead expected change in raw material costs was 2.78 percentage points for 255 firms which responded to this question.

- Panel-B provides 6-months ahead expected percentage change in skilled and unskilled worker employment. While firms expected skilled workers employment to increase by 1.05 percentage points, this figure was much lower for unskilled workers complemented by a higher standard deviation, indicating a decline in employment of unskilled workers in some firms.

- Panel-C reports firm's 6-months ahead expectations on wage changes for skilled and unskilled workers.

\section{BCIs of Firm s by Firm Size (Annual Turnover)}

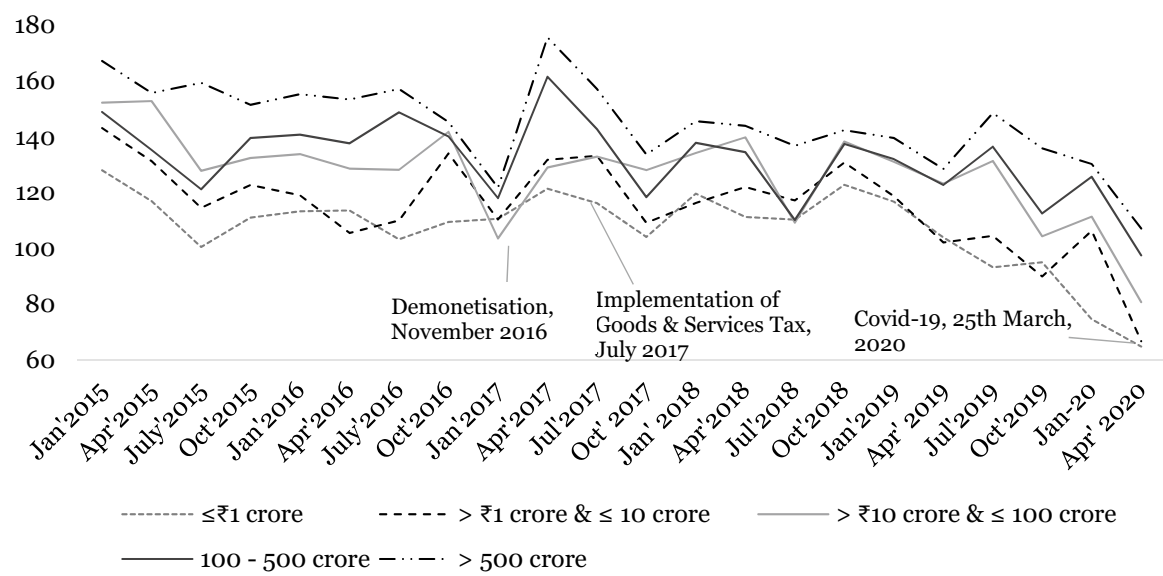

Fig. 1 BCIs of firms by firm size (annual turnover). Source: NCAER (2020) and previous rounds 
Business sentiments vary proportionately with firm size in almost all the rounds of N-BES. Figure 1 shows the business confidence index (N-BCI) by firm size. The $\mathrm{N}-\mathrm{BCI}$ of firms with annual turnover less than ₹ 1 crore fell from the high of 122.8 in October 2018 to 74.5 in January 2020 before falling further to 64.7 in March 2020. The N-BCI of firms with annual turnovers between ₹ 1-10 crore fell from 130.8 in October 2018 to 89.9 in October 2019. The N-BCI of firms with annual turnovers between ₹10-100 crore fell from 138.3 in October 2018 to 104.3 in October 2019. Both the N-BCIs for these two categories improved in January 2020 before sliding back again in March 2020 by (-) 37.3\% and (-) 27.6\%, respectively, on a quarter-onquarter (q-o-q) basis. The N-BCI of firms with annual turnovers between ₹100-500 crore behaved similarly as the other two. The N-BCI of firms with annual turnovers greater than ₹500 crore declined from 148.6 in July 2019 to 107.1 in March 2020.

\subsection{Meta data analysis}

Our objective in this paper is to compare change in sentiments before and after the announcement of lockdown (March 24th). If composition of firms changed before and after the lockdown, then a comparison of firms' sentiments between these two

Table 2 Meta data analysis

\begin{tabular}{|c|c|c|c|c|}
\hline & Before lockdown & After lockdown & Overall & $p$-value \\
\hline \multicolumn{5}{|l|}{ Panel-A: size distribution } \\
\hline $\begin{array}{l}\text { Small (annual turno- } \\
\text { ver }<\text { INR } 100 \text { crores) }\end{array}$ & $79.58 \%$ & $80.99 \%$ & $80.05 \%$ & 0.73 \\
\hline \multicolumn{5}{|c|}{ Panel-B: industrial sector distribution } \\
\hline Services & $44.01 \%$ & $31.69 \%$ & $39.91 \%$ & 0.014 \\
\hline Consumer goods & $28.17 \%$ & $35.92 \%$ & $30.75 \%$ & 0.102 \\
\hline Intermediate goods & $27.82 \%$ & $32.39 \%$ & $29.34 \%$ & 0.329 \\
\hline \multicolumn{5}{|c|}{ Panel-C: regional distribution } \\
\hline North & $35.56 \%$ & $34.51 \%$ & $35.21 \%$ & 0.83 \\
\hline South & $2.11 \%$ & $20.42 \%$ & $8.22 \%$ & 0.00 \\
\hline East & $33.11 \%$ & $19.01 \%$ & $28.40 \%$ & 0.0023 \\
\hline West & $29.23 \%$ & $26.06 \%$ & $28.17 \%$ & 0.49 \\
\hline \multicolumn{5}{|c|}{ Panel-D: ownership distribution } \\
\hline Public sector & $2.82 \%$ & $2.82 \%$ & $2.82 \%$ & 1.00 \\
\hline Private limited & $53.87 \%$ & $44.37 \%$ & $50.70 \%$ & 0.064 \\
\hline Public limited & $16.55 \%$ & $15.49 \%$ & $16.20 \%$ & 0.78 \\
\hline Partnership/ownership & $26.76 \%$ & $37.32 \%$ & $30.28 \%$ & 0.025 \\
\hline Total firms sampled & 284 & 142 & 426 & - \\
\hline
\end{tabular}

Source: Authors' computations from the NCAER BES survey round 112

${ }^{\#} p$ value from the $t$ test of the difference between the samples before and during the lockdown 
time periods may become unreliable. Table 2 provides a meta-data analysis of the distribution of firms sampled before and after the lockdown.

We classify firms into two sizes-'Small' with annual turnover less than or equal to INR 100 crores and 'Large' with annual turnover more than INR 100 crores. Size distribution of sampled firms remains invariant-nearly $80 \%$ of firms are sampled before and after lockdown. The $p$-value of the two-sample $t$ test for small-sized firms is 0.73 .

We consider three industrial categories - services, consumer manufacturing goods (consumer durable and non-durable goods) and intermediate manufacturing goods (capital and intermediate goods). Nearly $44 \%$ of firms sampled before lockdown were service sector firms, which fell to $31 \%$ after the lockdown. This decline was statistically significant. For consumer and intermediate goods, we found the respective proportions of firms sampled to be statistically similar.

Panel-C shows the regional distribution of firms. Southern region was under-represented which was mostly attributed to low sampling of southern firms before lockdown. Sampling of northern and western firms were statistically similar before and after lockdown.

Panel-D provides the distribution of firms by ownership type. Public sector firms formed the smallest group, which is usual for most N-BES. Reassuringly, they are equally represented before and after lockdown and so are public limited firms.

\section{Empirical methodology and results}

To explore the likelihood of how sentiments change in a lockdown, we use a logit probability model. Specifically, we use the following specification:

$$
I_{y}=f\left(I_{\text {Lockdown }}, \varphi_{\text {Size }}, \varphi_{\text {Industry }}, \varphi_{\text {Ownership }}, \varphi_{\text {Region }}\right)+\varepsilon
$$

where $I_{y}$ is a binary variable which takes value 1 if firm reflects a sentiment/expectations toward a variable, $y$, and 0 otherwise. $I_{\text {Lockdown }}$ is a binary variable which takes value 1 if firm was interviewed on or after 22 nd March and 0 otherwise.

The coefficient on $I_{\text {Lockdown }}$ reflects the change in sentiments due to the lockdown. Logit model allows computing predicted probability of $I_{y}=1$ if $I_{\text {Lockdown }}=1$. We will report this measure in subsequent analysis.

We control for various firm characteristics to account for heterogeneity in sentiments by firm size $\left(\varphi_{\text {Size }}\right)$, industrial sector $\left(\varphi_{\text {Industry }}\right)$, ownership type $\left(\varphi_{\text {Ownership }}\right)$ and region $\left(\varphi_{\text {Region }}\right)$. A fixed effect for each characteristics absorbs away firm-specific heterogeneity. There are altogether 9 dummy variables for such characteristics - 1 for firm size, 2 for industrial sector, 3 for ownership type and 3 for the region. Apart from the coefficient on the Lockdown indicator, we will also report firm-size and industry-size effects to understand industry and size heterogeneities.

\subsection{Expectation of firm's condition worsening in 6 months}

We first explore how a firm's sentiment regarding its own conditions changed in lockdown compared to the period before that. 
To explore the relationship rigorously, we use the following logit model:

$$
I_{\text {WorseCondition }}=f\left(I_{\text {Lockdown }}, \varphi_{\text {Size }}, \varphi_{\text {Industry }}, \varphi_{\text {Ownership }}, \varphi_{\text {Region }}\right)+\varepsilon
$$

where $I_{\text {WorseCondition }}$ is a binary variable which takes value 1 if firm believes its own financial condition will worsen in 6 months and 0 otherwise. The intuitively expected sign on the lockdown is positive as it would tend to worsen business sentiments.

Table 3 reports the predicted probability in the lockdown of a firm expecting its condition to worsen in the next 6 months. The coefficient on the Lockdown indicator is 0.109 with a standard error of 0.034 - firms surveyed during the lockdown were $10 \%$ more likely to expect their conditions to worsen over the next 6 months.

Small and large firms do not appear to be different in their perception of worsening conditions. However, we find considerable sectoral heterogeneity. Compared to the consumer goods industry, service sector firms were $16 \%$ likely to expect their conditions to worsen over the next 6 months.

\subsection{Perception for worsening conditions}

At the time of the lockdown, the disruption had the potential of being both a demand and supply shock. On one hand, businesses could have expected unstable supply chains. On the other, consumers also became risk-averse exhibiting a downward demand shift. In this section, we will explore which factors did firms perceive as more detrimental? - demand or supply.

Demand-related expectations are derived from responses on expected changes to domestic sales 6 months from now. We constructed a binary variable, $I_{\text {DemandSentiment }}$,

Table 3 Perception of demand and supply shocks

\begin{tabular}{lc}
\hline & $\operatorname{Pr}($ sales will decline) \\
\hline Lockdown & $0.109 * *(0.034)$ \\
$\begin{array}{l}\text { Firm-size effect (base group: firms with annual turnover }>\text { Rs. } 100 \\
\text { crores) }\end{array}$ \\
Small & $0.038(0.040)$ \\
Industry-level effects (base group: consumer goods manufacturing) \\
Services & $-0.16^{* * *}(0.0404)$ \\
Intermediate goods manufacturing & $-0.065(0.040)$ \\
Observations & 426 \\
\hline
\end{tabular}

Source: Authors' computations from the NCAER BES survey round 112

Notes: Dummies for Industrial Sector, Ownership Type and Region characteristics of the firm are included in both models. Size and Industry-wise coefficients reported in the table to explore heterogeneity. Full results are available in the Electronic Supplementary Material

$* * * / * * / *$ Denote significance at $1 / 5 / 10$ percent level respectively. Standard errors are reported in parenthesis 
which takes value 1 if firms expect a decline in 6-months ahead expected sales compared to the present situation, and 0 otherwise. 288 firms responded to this question. We would expect a positive sign on this coefficient if the lockdown worsened business sentiments.

Similarly, expectations on 6-months ahead cost of raw material constitutes supply-related sentiments. A binary variable, $I_{\text {Supplysentiment }}$, is 1 if firm expected costs of raw materials to go up, and 0 otherwise. This information is available for 255 firms. The sign on this coefficient would be positive implying that the lockdown worsened as supply-side constraints would drive up costs.

We regress $I_{\text {DemandSentiment }}$ and $I_{\text {SupplySentiment }}$ on lockdown indicator along with all the firm characteristics. If the coefficients on the lockdown is positive in both regressions, then firms perceived the lockdown as a demand as well as a supplyside shock.

Table 4 shows the results. In the lockdown period, a firm is $11.2 \%$ more likely to expect a worsening of demand-side conditions - a decline in 6-months ahead domestic sales. Demand-related sentiments for small firms were poorer compared to large firms to begin with. Thus, the lockdown had deteriorated their expectations of the future further. Firms across industries did not vary in their perception of demandshock. However, small-sized firms were more likely to expect a fall in sales.

Table 4 also shows firms' expectations on supply-related factors. As opposed to the demand side risks, supply-side risks appeared to be on the downside. In lockdown, a firm was $19.1 \%$ less likely to expect raw material costs to go up. Smaller firms expected a higher softening of raw material costs but it was not statistically significant. For this sentiment, industry and size heterogeneities were non-existent.

Results in Table 4 indicate which factor firms perceive are likely to be more detrimental in the near future. While firms expected demand conditions to worsen when lockdown was announced, a similar worsening of sentiment for supply-condition was not observed.

Table 4 Perception of demand and supply shocks

\begin{tabular}{lll}
\hline & Pr (sales will decline) & $\begin{array}{l}\text { Pr (raw material } \\
\text { costs will go up) }\end{array}$ \\
\hline Lockdown & $0.112^{* *}(0.047)$ & $-0.191^{* * *}(0.050)$ \\
Firm-size effect (base group: firms with annual turnover $>$ Rs. 100 crores $)$ & $-0.110(0.067)$ \\
Small & $0.112^{*}(0.065)$ & \\
Industry-level effects (base group: consumer goods) & & $0.019(0.076)$ \\
Services & $0.051(0.063)$ & $0.063(0.051)$ \\
Intermediate goods manufacturing & $-0.008(0.051)$ & 255 \\
Observations & 288 &
\end{tabular}

Source: Authors' computations from the NCAER BES survey round 112

Notes: Dummies for Industrial Sector, Ownership Type and Region characteristics of the firm are included in both models. Size and Industry-wise coefficients reported in the table to explore heterogeneity. Full results are available in the Electronic Supplementary Material

$* * * / * * / *$ Denote significance at $1 / 5 / 10$ percent level respectively. Standard errors are reported in parenthesis 


\subsection{Potential mitigation response}

How are firms likely to respond to the worsening demand-side conditions? In the short run, firms can adjust labour hiring decisions to reduce costs.

We asked firms about the expected change in employment of skilled and unskilled workers in the next 6 months. We used these variables to construct indicators for potential mitigation response by firms. Specifically, we constructed a variable, $I_{\text {SkilledWorker }}\left(I_{\text {UnskilledWorker }}\right)$, which was 1 if firms claim they expect the same employment of skilled workers (unskilled workers) to increase or stay the same in the next 6 months in their firm, and 0 otherwise. We had 315 (268) responses for $I_{\text {SkilledWorker }}$ $\left(I_{\text {UnskilledWorker }}\right)$, respectively. A positive coefficient implies that firms' employment sentiments remain positive despite the lockdown.

Table 5 shows how these employment expectations change during the lockdown. When lockdown was announced, a firm was $8.9 \%$ more likely to decrease skilled workers employment. The response toward unskilled workers was much steeper; a firm was $17.6 \%$ more likely to decrease the employment of unskilled workers in the next 6 months. Service sector firms were less likely to increase the employment of unskilled workers compared to consumer goods firms. There appeared to be no significant differences between small and large firms related to the employment changes 6 months from March 2020.

Another mitigating response for firms is to reduce wage hikes to workers. We asked firms about the expected change in wages for skilled and unskilled workers in the next 6 months, and constructed binary variables which reflected if the firm expected to increase skilled workers' (unskilled workers) wages by at least 5\%. A positive coefficient implies that firms would increase wages despite the lockdown.

Table 6 shows the results of a logit model. The probability of a firm to increase the wages of skilled workers by $5 \%$ reduced by $26.6 \%$. The corresponding figure for

Table 5 Expected employment changes in firm in next 6 months

\begin{tabular}{lll}
\hline & $\begin{array}{l}\text { Pr (employment of } \\
\text { skilled workers will } \\
\text { increase) }\end{array}$ & $\begin{array}{l}\text { Pr (employment of } \\
\text { unskilled workers will } \\
\text { increase) }\end{array}$ \\
\hline Lockdown & $\begin{array}{l}-0.089 * * *(0.028) \\
\text { Firm-size effect (base group: firms with annual turnover }>\text { Rs. } 10 \text { crores })\end{array}$ & $-0.176^{* * *}(0.039)$ \\
Small & $-0.035(0.036)$ & $-0.035(0.066)$ \\
Industry-level effects (base group: consumer goods) & & $-0.114 * *(0.054)$ \\
Services & $-0.029(0.034)$ & $-0.052(0.046)$ \\
Intermediate goods manufacturing & $0.011(0.034)$ & 268 \\
Observations & 315 & \\
\hline
\end{tabular}

Source: Authors' computations from the NCAER BES survey round 112

Note: Dummies for Industrial Sector, Ownership Type and Region characteristics of the firm are included in both models. Size and Industry-wise coefficients reported in the table to explore heterogeneity. Full results are available in the Electronic Supplementary Material

$* * * / * * / *$ Denote significance at $1 / 5 / 10$ percent level respectively. Standard errors are reported in parenthesis 
Table 6 Expected wage changes in firm in next 6 months

$\operatorname{Pr}$ (wage of skilled work- $\operatorname{Pr}$ (wage of unskilled ers will increase by 5\%) workers will increase by $5 \%)$

\begin{tabular}{lll} 
Lockdown & $-0.258^{* * *}(0.049)$ & $-0.166^{* * *}(0.05)$ \\
Firm-size effect (base group: firms with annual turnover $>$ Rs. 10 crores $)$ & \\
Small & $-0.152(0.05)$ & $0.021(0.060)$ \\
Industry-level effects (base group: consumer goods) & $-0.016(0.055)$ & $0.132 * *(0.054)$ \\
Services & $-0.067(0.050)$ & $-0.115^{* *}(0.053)$ \\
Intermediate goods manufacturing & 352 & 326 \\
Observations & 352 \\
\hline
\end{tabular}

Source: Authors' computations from the NCAER BES survey round 112

Notes: Dummies for Industrial Sector, Ownership Type and Region characteristics of the firm are included in both models. Size and Industry-wise coefficients reported in the table to explore heterogeneity. Full results are available in the Electronic Supplementary Material

$* * * / * * / *$ Denote significance at $1 / 5 / 10$ percent level respectively. Standard errors are reported in parenthesis

unskilled workers is $20.1 \%$. Thus, firms were more likely to reduce wage hikes for skilled workers compared to unskilled ones.

Coefficients on the services sector and intermediate sector dummy were insignificant in a model for wage hikes for skilled workers. However, for unskilled workers, we find while service sector firms were likely to increase wages, intermediate goods firms were less likely to offer wage hikes. Small and large firms appeared to have similar sentiments related to wage changes for their skilled and unskilled workers.

\section{Discussions}

In this paper, we find that the imposition of the lockdown worsened the sentiments for firms drastically. Importantly, firms expected this shock as a demand-side disruption with expectations of domestic sales declining rapidly during lockdown compared to the period before. The probability of firms expecting a reduction in raw material costs during that period increased during the lockdown. An unusually sober response to supply-side sentiments appears striking as supply chains were disrupted. The NCAER Survey also does not support any accumulation of inventories. This puzzling result requires more investigation.

We also find firms were likely to reduce employment and wage hikes for workers in the short run. Interestingly, the nature of response depended on the type of the worker-firms were more likely to reduce unskilled workers' employment but more likely to restrict wage hikes for skilled workers. This is understandable since skilled worker employment is bound by contract which restricts contractionary action whereas for unskilled worker employment is more fluid.

The results have several insights. First, expecting poor demand for final products may imply a lower production by firms. Self-fulfilling nature of expectations may have fueled 
a vicious cycle of low production, low income generation, low demand and hence low production. Thus, a credible, macro-fiscal stimulus was needed urgently to break this cycle and not simply infusion of credit, which was ineffective without complementary consumer spending. Secondly, firms appeared to adjust labour costs in the short-run. In this light, the waiver of non-wage costs, such as Employee Provident Fund contribution, by the government for registered employees was the right decision. However, that measure was less relevant for unskilled workers who were usually unregistered. A similar measure was needed which would have allowed firms to retain unskilled workers.

While this survey was conducted in March 2020, the second wave of the pandemic led to lockdowns in several states in India. The results, thus, still hold value for many state governments which now are slowly withdrawing these restrictions. In addition, the results also hold value for the potential business disruption if a third wave also strikes. A push to increase consumer spending would help businesses find their footing faster ultimately helping the overall economy to climb out of the recessions faster.

\section{Appendix 1}

\section{N-BCI and IIP}

Sample: 2011Q1 2020Q1

Included observations: 32

Correlations are asymptotically consistent approximations

\begin{tabular}{|c|c|c|c|c|c|c|c|}
\hline IIP_SA_CYC_ & & C) & c. & & & lag & lead \\
\hline 1 & & 1 & & & 0 & 0.4499 & 0.4499 \\
\hline 1 & & 1 & 드 & I & 1 & 0.3583 & -0.0958 \\
\hline$\square$ & 1 & 1 & & 1 & 2 & -0.1525 & 0.0055 \\
\hline 1 & 1 & 1 & & । & 3 & 0.2127 & -0.0127 \\
\hline $1 \square$ & 1 & 1 & 다 & 1 & 4 & -0.1391 & -0.0567 \\
\hline 15 & 1 & 1 & & 1 & 5 & 0.1565 & 0.0183 \\
\hline 1 & 1 & 1 & & 1 & 6 & 0.0968 & 0.0210 \\
\hline $1 \square$ & । & 1 & $\square$ & I & 7 & -0.1625 & -0.1399 \\
\hline 1 & । & । & & I & 8 & 0.1607 & 0.0258 \\
\hline 1 & । & । & 단 & 1 & 9 & -0.0154 & -0.1184 \\
\hline $1 \square$ & । & 1 & 다 & । & & -0.1743 & -0.0811 \\
\hline 1 & । & । & 7 & । & & 0.1522 & 0.0451 \\
\hline 1 & I & । & 다 & । & & -0.0479 & -0.0678 \\
\hline $1 \square$ & । & 1 & & I & & -0.2439 & 0.0177 \\
\hline 15 & 1 & 1 & & । & & 0.1802 & 0.1512 \\
\hline i & 1 & 1 & 니 & I & & -0.0592 & -0.0521 \\
\hline 1 & । & 1 & | & 1 & & -0.0141 & -0.0114 \\
\hline
\end{tabular}


Source: NCAER BES Several Rounds.

Note: BCIGR stands for the growth rate of BCI and IIP_SA_CYC_GR is the growth rate of the seasonally adjusted cyclical component of IIP.

\section{Appendix 2}

\section{N-BCI and GVA manufacturing}

Sample: 2011Q1 2020Q1

Included observations: 36

Correlations are asymptotically cons is tent approximations

\begin{tabular}{|c|c|c|c|c|c|c|}
\hline GVAM_SA_CYC & _GR,BCl... & GVAM_SA_C & _GR,BCl... & $\mathrm{i}$ & lag & lead \\
\hline $1 \square$ & 1 & IL & 1 & 0 & -0.2905 & -0.2905 \\
\hline$\square$ & 1 & 1 & 1 & 1 & -0.2081 & 0.0373 \\
\hline 1 & 1 & 1 & 1 & 2 & 0.0889 & 0.1108 \\
\hline $1 \square$ & 1 & 1 प & 1 & 3 & -0.1840 & -0.0661 \\
\hline 1 & 1 & 1 & ا] & 4 & -0.0505 & 0.2894 \\
\hline 1 & 1 & 1 & 1 & 5 & -0.0025 & -0.0495 \\
\hline 1 & 1 & $1 \sqsubset$ & 1 & 6 & -0.0227 & -0.1079 \\
\hline & 1 & 1 & 1 & 7 & 0.2135 & 0.1257 \\
\hline I & 1 & 1 & 1 & 8 & -0.0253 & -0.0353 \\
\hline 15 & $\square$ & 1 다 & 1 & 9 & 0.2966 & -0.0979 \\
\hline 1 디 & 1 & 1 & 1 & 10 & -0.0769 & 0.2389 \\
\hline 1 다 & 1 & 1 & 1 & 11 & -0.0792 & 0.0493 \\
\hline प다 & 1 & 1 & 1 & 12 & -0.0598 & 0.0409 \\
\hline $1 \quad$ & 1 & 1 & 1 & 13 & 0.0780 & 0.0934 \\
\hline $1 \square$ & 1 & $1 \square$ & 1 & 14 & -0.1414 & -0.1193 \\
\hline 1 & 1 & 1 & 1 & 15 & 0.0018 & 0.1567 \\
\hline 1 & 1 & $\square$ & 1 & 16 & 0.1249 & -0.3082 \\
\hline
\end{tabular}

Source: NCAER BES Several Rounds.

Note: GVAM_SA_CYC_GR is the growth rate of the seasonally adjusted cyclical component of GVA manufacturing. 


\section{Appendix 3}

\section{Engle-Granger causality results}

\begin{tabular}{lclc}
\hline Null hypothesis: & Obs & F-statistic & Prob \\
\hline $\begin{array}{l}\text { BCIGR does not Granger cause } \\
\text { IIP_SA_CYC_GR }\end{array}$ & 30 & 2.63537 & 0.0915 \\
\begin{tabular}{l} 
IIP_SA_CYC_GR does not Granger cause BCIGR \\
\hline
\end{tabular} & 0.74098 & 0.4868 \\
\hline
\end{tabular}

$N=30$.

Supplementary Information The online version contains supplementary material available at https://doi. org/10.1007/s41775-021-00121-w.

Acknowledgements We thank Jaskirat Singh Kohli for providing us with research assistance during the BES Survey.

Funding The authors hereby declare that funding for the survey was provided by NCAER. The authors are grateful to NCAER for allowing them to use the data.

\section{Declarations}

Conflict of interest The authors do not stand to gain financially due to the publication of the manuscript.

\section{References}

Baker, S. R., Bloom, N., Davis, S. J., \& Terry, S. J. (2020a). Covid-induced economic uncertaint. National Bureau of Economic Research. https://doi.org/10.3386/w26983

Baker, S. R., Bloom, N., Davis, S. J., Kost, K. J., Sammon, M. C., \& Viratyosin, T. (2020b). The unprecedented stock market impact of COVID-19. National Bureau of Economic Research. https://doi.org/ $10.3386 /$ w26945

Banerjee, A., \& Marcellino, M. (2006). Are there any reliable leading indicators for US inflation and GDP growth? International Journal of Forecasting, 22, 137-151.

Bell, C., \& Lewis, M. (2005). Economic implications of epidemics old and new. SSRN. https://doi.org/10. 2139/ssrn.997387

Christiansen, C., Eriksen, J. N., \& Møller, S. V. (2014). Forecasting US recessions: the role of sentiment. Journal of Banking and Finance, 49, 459-468.

Eichenbaum, M. S., Rebelo, S., \& Trabandt, M. (2020). The macroeconomics of epidemics. National Bureau of Economic Research. https://doi.org/10.3386/w26822

Hale, T., Noam A., Kira, B., Petherick, A., Phillips, T. and Webster, S. (2020). Variation in Government responses to COVID-19 version 5.0. Blavatnik School of Government Working Paper. April 29. Available: www.bsg.ox.ac.uk/covidtracker. Accessed 02 May 2020

Hassan, T. A., Hollander, S., van Lent, L., \& Tahoun, A. (2020). Firm-level exposure to epidemic diseases: covid-19, SARS, and H1N1. National Bureau of Economic Research. https://doi.org/10.3386/ w26971

Hatchett, R. J., Mecher, C. E., \& Lipsitch, M. (2007). Public health interventions and epidemic intensity during the 1918 influenza pandemic. Proceedings of the National Academy of Sciences, 104(18), 7582-7587. https://doi.org/10.1073/pnas.0610941104 
Hodrick, R. J., \& Prescott, E. C. (1997). Postwar US business cycles: an empirical investigation. Journal of Money, Credit \& Banking, 29(1), 1-16.

Kauffman, R. G. (1999). Indicator quality of the NAPM report on business. The Journal of Supply Chain Management., 35(2), 29-37.

Klein, P. A., \& Moore, G. H. (1991). Purchasing management survey data: their value as leading indicators. In K. Lahiri \& G. H. Moore (Eds.), Leading economic indicators: new approach and forecasting records. Cambridge: Cambridge University Press.

Koenig, E. (2002). Using the purchasing managers' index to assess the economy's strength and the likely direction of monetary policy. Economic and Financial Policy Review, Federal Reserve Bank of Dallas., 1(6), 1-14.

Lahiri, K., \& Monokroussos, G. (2013). Nowcasting US GDP: The role of IMS business surveys. International Journal of Forecasting., 29, 644-658.

Lindsey, M. D., \& Pavur, R. J. (2005). As the PMI turns: A tool for supply chain managers. The Journal of Supply Chain Management., 41(3), 30-39.

National Council of Applied Economic Research (NCAER). 2020. Business Expectations Survey Round 112. April. Available upon request

OECD. (2020). Business confidence index (BCI) (indicator). OCED. https://doi.org/10.1787/3092dc4f-en

Press Information Bureau (PIB). (2020a). Government of India issues Orders prescribing lockdown for containment of COVID-19 Epidemic in the country. https://pib.gov.in/newsite/PrintRelease.aspx? relid=200655. March 24. Accessed 04 May 2020

Press Information Bureau (PIB). (2020b). PM addresses the nation for 4th time in 4 Weeks in India's fight against COVID-19, Announces extension of lockdown till 3rd May, High Risk Areas and Hotspots to be under constant vigil, Ease of Certain Restrictions in Low Risk Areas from 20 April, Detailed guidelines to be issued by the Government tomorrow and PM seeks support for seven things including taking care of elderly and adhering to social distancing and lockdown. https://pib.gov.in/Press ReleseDetail.aspx?PRID=1614255. April 14. Accessed 04 May 2020

Publisher's Note Springer Nature remains neutral with regard to jurisdictional claims in published maps and institutional affiliations. 